\title{
Addition of a surfactant to water increases the acaricidal activity of extracts of some plant species used to control ticks by Zimbabwean smallholder farmers
}

\author{
Emmanuel T. Nyahangare ${ }^{1,2}$, Brighton M. Mvumi ${ }^{3}$, Lyndy J. McGaw² and Jacobus N. Eloff ${ }^{2}$ (D)
}

\begin{abstract}
Background: Many studies have revealed that bioactive compounds for different indications are not extracted from plants with water, the only extractant practically available to rural communities. We compared the acaricidal activity of acetone extracts of 13 species used traditionally to protect cattle against ticks. We also investigated if the extraction of biologically active compounds against Rhipicephalus (Boophilus) decoloratus ticks could be enhanced by adding a liquid soap that is locally available to smallholder farmers.

Methods: A total of 13 plant species selected based on reported traditional use in Zimbabwe, were dried and finely ground before extraction with water, or water plus a surfactant, or acetone. The adapted Shaw Larval Immersion Test (SLIT) method was used to determine the activity of acetone and crude water extracts with or without liquid soap against the tick larvae. The activity of four fractions of crude acetone extracts (extracted using solvents of different polarity), of the most active plant species, Maerua edulis (tuber and leaf) was also compared to identify the most active fraction.

Results: Aqueous plant extracts were not toxic to ticks, but the addition of $1 \%$ liquid soap as a surfactant increased mortality of the R. (B) decoloratus larvae significantly. With the Maerua edulis tuber extract, the efficacy of the 1\% liquid soap was comparable to that of the amitraz based commercial synthetic acaricide. The use of acetone as an extractant, also increased the mortality of the tick larvae in all the plant species. With M. edulis (tuber and leaf), Monadenium lugardae and Kleinia sp. acetone extracts, the activity was comparable to that of the positive control (a commercially available amitraz-based synthetic acaricide). The non-polar fractions of the acetone extract of leaf and tuber of M. edulis caused up to $100 \%$ mortality. This indicates that non-polar to intermediate polarity compounds are responsible for the acaricidal activity.
\end{abstract}

Conclusion: Organic solvents such as acetone extracted active compounds but water did not. By adding commonly available dishwashing soap to water active compounds were extracted leading to a high acaricidal activity of the plant extracts. In some cases, it was as active as non-polar extracts and a synthetic commercial acaricide (positive control). This approach makes it possible for the smallholder farmers and traditional healers to extract biologically active compounds from plants by using water.

Keywords: Water extracts, Acetone, Solvent-solvent fractionation, Cattle tick, SLIT bioassay, Tick larvae mortality, Biological activity

\footnotetext{
* Correspondence: kobus.eloff@up.ac.za

${ }^{2}$ Phytomedicine Programme, Faculty of Veterinary Science, University of

Pretoria, Private Bag X04, Onderstepoort, Pretoria 0110, South Africa

Full list of author information is available at the end of the article
}

(c) The Author(s). 2019 Open Access This article is distributed under the terms of the Creative Commons Attribution 4.0 International License (http://creativecommons.org/licenses/by/4.0/), which permits unrestricted use, distribution, and reproduction in any medium, provided you give appropriate credit to the original author(s) and the source, provide a link to the Creative Commons license, and indicate if changes were made. The Creative Commons Public Domain Dedication waiver (http://creativecommons.org/publicdomain/zero/1.0/) applies to the data made available in this article, unless otherwise stated. 


\section{Background}

Ticks cause major problems to optimal livestock productivity and may also cause human diseases especially in tropical parts of the world by the transfer of pathogens [1]. Ticks also affect animals through tick-worry and hide damage [2]. The global cost of managing and controlling ticks and tick-borne diseases are estimated to be several billions of United States dollars annually [3]. For many years, chemical control using synthetic acaricides has been the preferred control strategy but there are now several legitimate issues against their extensive use. Synthetic acaricides are expensive, active environmental pollutants, have been found as residues in animal products and their continual use has led to development of tick resistance to most acaricides on the market [4]. These are some of the issues that researchers are trying to address by investigating alternative or complementary products that farmers can use.

Many scientists are investigating the use of botanical pesticides as effective, safe and environmentally benign products against ticks [5]. Historically, plants played pivotal roles in agricultural pest management, but the advent of synthetic compounds had reduced this role. There is, consequently, a need to identify and verify activity of plants that are useful from the many plant species in the world. This is already a budding industry with potential to alleviate the challenges of tick control using synthetic products. There are several recent review papers that address various aspects such as: which plants have been used traditionally to combat ticks [4]; the methodologies used to test efficacy of these plants [6]; the use of essential oils as deterrents [7]; and a meta-analysis of compounds with activity against ticks [8].

Systematic and standardised determination of in vitro efficacy is a crucial step in the development of botanical acaricides. Farmers often report acaricidal efficacy of some traditional plants against cattle ticks $[2,9,10]$ and evidence for this efficacy is required. Laboratory testing helps to determine the effective plant extracts under controlled reproducible conditions. This allows resources for product development to be channelled towards these candidate plant species. One strategy is to start by mimicking farmer practice in the laboratory to determine if farmer observation or experience is replicable in vitro and subsequently in vivo. Most farmers, have only water available as an extractant. It has, however, been established that water alone is not an effective extractant to use for plant-based products because many biologically active compounds are not soluble in water [11].

In a review on research of acaricidal activity of plants, Adenubi et al. [8], listed extractants used by different authors in 392 publications. Acetone was used in $44 \%$ of the publications followed by ethyl acetate (20\%), petroleum ether (13\%), chloroform $(12 \%)$, methanol (4\%), water (4\%) and hexane (3\%). The low percentage of water used is also an indication that it is not a good extractant for acaricidal compounds. The general efficacy of crude acetone extract for most of the plant species is a clear indication that the active compounds may be of intermediate polarity. Acetone has excellent ability to extract plant-based active compounds in plants and has been used by many researchers $[11,12]$. The high percentage of authors using acetone as extractant for acaricidal activity also indicates its low toxicity to ticks $[8]$.

Organic solvents produce better results than water, particularly acetone because of its ability to dissolve cell membranes and extracts both polar and nonpolar compounds. It has a low toxicity to target test organisms such as microorganisms [11] and ticks [13]. It has also been shown that solvent-solvent fractionation into different polarity fractions may increase efficacy of plant extracts [14]. Some low-cost measures that can be used include the use of a surfactant and hot water for extraction purposes [15]. In this study, we examined the acaricidal activity of acetone and water extracts with and without a surfactant of different plant species that rural farmers in Zimbabwe use to protect their cattle against ticks. We used Rhipicephalus (Boophilus) decoloratus, a very important cattle tick in southern Africa as a test organism in the in vitro assays. We also investigated whether solvent-solvent fractionation could increase the activity of an acetone extract with high activity to facilitate the isolation and characterization of the active compound(s) in the fractions.

The overall objective of the study was to determine the in vitro efficacy of different extractants and fractions of selected plant species against cattle ticks. Based on previous work $[15,16]$, special attention was given to M. edulis.

\section{Results}

\section{Activity of crude water extracts}

When water only was used as an extractant, the extracts had no acaricidal activity with no significant difference with the negative control (distilled water). The addition of a surfactant to water led to an amazing increase in activity compared to the negative control (water with surfactant) in some of the species examined (Table 1). The highest mortality was recorded in the $M$. edulis tuber that was as effective as the amitraz-based positive control $(P>0.05)$. The extracts of $M$. lugardae and $M$. edulis leaves led to mortalities that were below 50\% (Table 1). There was no significant difference $(P>0.05)$ between 
Table 1 Corrected mortality (\%) of tick larvae exposed to crude water and water with surfactant extracts $(100 \mathrm{mg} / \mathrm{mL})$ of six plant species and Amitraz ( $2 \mathrm{~mL} / \mathrm{L}, ; 0.002 \%)(\mathrm{N}=4)$

\begin{tabular}{lll}
\hline Plant species & Mean mortality (\%) & $\begin{array}{l}\text { Corrected mortality } \\
\pm \text { SEM (\%) }\end{array}$ \\
\hline Maerua edulis (tuber) & 97.5 & $97.4 \pm 0.96^{\mathrm{a}}$ \\
Monadenium lugardae (stems) & 32.3 & $30.6 \pm 0.96^{\mathrm{b}}$ \\
Maerua edulis (leaves) & 15.4 & $13.3 \pm 3.30^{\mathrm{c}}$ \\
Cissus quadrangularis (stems) & 4.2 & $1.7 \pm 2.34^{\mathrm{d}}$ \\
Aloe vera (stems) & 5.0 & $2.6 \pm 3.10^{\mathrm{d}}$ \\
Datura stramonium (leaves) & 19.2 & $17.5 \pm 4.84^{\mathrm{c}}$ \\
Cassia abbreviata (leaves) & 17.7 & $15.6 \pm 10.16^{\mathrm{c}}$ \\
Water with surfactant & 2.49 & $0 \pm 0.87^{\mathrm{d}}$ \\
(negative control) & & $100^{\mathrm{a}}$ \\
Amitraz (positive control) & 100 & $0^{\mathrm{d}}$ \\
Water without surfactant & 0 &
\end{tabular}

Superscripts with different letters in a column denote treatments that differ statistically $(P<0.05)$

the negative control and the C. quadrangularis, A. vera and C. abbreviata extracts.

\section{Activity of crude acetone extracts}

In general, the acetone extracts had higher activity against the tick larvae than water or water with surfactant (Table 2). The most effective acetone extracts were of the M. edulis (leaf and tuber) and Kleinia sp. (Table 2). There was no statistically significant difference in activity

Table 2 Corrected mortality (\%) of tick larvae caused by acetone extracts $(100 \mathrm{mg} / \mathrm{mL})$ of different plant species $(N=4)$

\begin{tabular}{lll}
\hline Plant species & Mean mortality (\%) & $\begin{array}{l}\text { Corrected } \\
\text { mortality } \pm \text { SEM (\%) }\end{array}$ \\
\hline Maerua edulis (leaf) & 97 & $97 \pm 3.3^{\mathrm{a}}$ \\
Maerua edulis (tuber) & 93 & $93 \pm 6.7^{\mathrm{a}}$ \\
Kleinia sp. & 90 & $90 \pm 5.8^{\mathrm{a}}$ \\
Monadenium lurgadae & 83 & $83 \pm 3.3^{\mathrm{b}}$ \\
Cassia abbreviata & 77 & $77 \pm 6.7^{\mathrm{b}}$ \\
Cissus quadrangularis & 57 & $57 \pm 6.7^{\mathrm{c}}$ \\
Aloe excelsa & 53 & $53 \pm 16.7^{\mathrm{c}}$ \\
Osyris lanceolata & 53 & $53 \pm 12.2^{\mathrm{c}}$ \\
Albizia amara & 43 & $43 \pm 13.3^{\mathrm{d}}$ \\
Ricinus communis & 43 & $43 \pm 14.5^{\mathrm{d}}$ \\
Carissa edulis & 37 & $37 \pm 14.5^{\mathrm{d}}$ \\
Terminalia sericea & 27 & $27 \pm 12.0^{\mathrm{e}}$ \\
Croton gratissimus & 23 & $23 \pm 8.8^{\mathrm{e}}$ \\
Ornithogalum sp. & 20 & $20 \pm 20^{\mathrm{e}}$ \\
Amitraz (positive control) & 100 & $100^{\mathrm{a}}$ \\
Acetone (negative control) & 0 & $0^{\mathrm{f}}$
\end{tabular}

Corrected mortality values with different superscripts letters are significantly different within the column $(P<0.05)$ between these treatments and the amitraz-based positive control. The acetone extracts of $M$. lugardae and $C$. abbreviata showed higher activities of 83 and $77 \%$ corrected mortalities respectively. With the exception of $A$. vera stems and $C$. quadrangularis stems, all the extracts of the other plants had significantly higher activity than the negative control acetone. The activities of the other plant extracts varied from 20 to $57 \%$ corrected mortality (Table 2). There was a high correlation between the activities of the top acetone extracts and the plants extracted using water and a surfactant $\left(R^{2}=0.997\right)$.

\section{Solvent-solvent fractionation}

The chloroform fractions of the M. edulis tuber and leaf and the hexane and butanol fractions of M. edulis tuber were the most effective fractions against tick larvae and had no significant difference with the activity of the positive control (amitraz). The other fractions were not as effective (Table 3$)$.

\section{Discussion}

In evaluating the activity of the different extractants, it would have been useful to determine the activity of different concentrations, but this would have meant much additional work. We decided to use a $10 \%$ concentration as in our previous publications, because this makes it easy to compare results. Despite being highly rated by farmers [9], no water extracts were effective against the ticks under controlled conditions. Other authors have found that water alone does not extract antimicrobial or pesticidal compounds from plant material because of its high polarity $[11,17]$. The most likely compounds to be extracted by water include proteins, sugars and salts which are not toxic to parasites [18]. The possible explanation for the difference may be that rural farmers do not use sterile distilled water. If there are

Table 3 Corrected mortality (\%) of tick larvae treated with solvent- solvent fractions of the acetone extract $(10 \mathrm{mg} / \mathrm{mL})$ of M. edulis leaves $(L)$ or tubers $(T)$ and Amitraz $(0.002 \% \mathrm{v} / \mathrm{V})(\mathrm{N}=4)$

\begin{tabular}{lll}
\hline Plant extract & Mean mortality (\%) & $\begin{array}{l}\text { Corrected } \\
\text { mortality } \pm \text { SEM (\%) }\end{array}$ \\
\hline Maerua edulis (L) water & 32.5 & $27.2 \pm 8.54^{\mathrm{c}}$ \\
Maerua edulis (L) butanol & 2.0 & $5.7 \pm 0.41$ \\
Maerua edulis (L) chloroform & 100.0 & $100.0 \pm 0^{\mathrm{a}}$ \\
Maerua edulis (L) hexane & 51.5 & $47.7 \pm 18.53^{\mathrm{b}}$ \\
Maerua edulis (T) butanol & 96.3 & $96.0 \pm 2.39^{\mathrm{a}}$ \\
Maerua edulis (T) chloroform & 100.0 & $100.0 \pm 0^{\mathrm{a}}$ \\
Maerua edulis (T) hexane & 100.0 & $100.0 \pm 0^{\mathrm{a}}$ \\
Amitraz (positive control) & 100.0 & $100.0 \pm 0^{\mathrm{a}}$ \\
Diluent (negative control) & 7.2 & - \\
\hline
\end{tabular}

Corrected mortality values with different superscript letters within the column are significantly different $(P<0.05)$ 
microorganisms in the water that could grow on nutrients present in the plant material, and extraction takes place over a long period, intermediate polarity compounds can be solubilized and kill ticks. Physical factors such as photo-oxidation and temperature may also play a role. It is also possible that some plants contain saponins that act as soap and solubilise intermediate polarity compounds. Finally, the concentrations used by farmers could be higher than the $100 \mathrm{mg} / \mathrm{mL}$ used in this study.

It is difficult to discard water as a useful solvent because it is the only extractant generally available and most ethnoveterinary medicines are based on water extracts [19]. The possibility of using water with something added that would solubilize intermediate polarity compounds is logical.

In the solvent-solvent fractionation of the acetone extract of M. edulis, the chloroform fraction had the highest activity. This confirms results found in investigating the activity of different extractants and fractions against several microorganisms $[14,20,21]$. It appears that the compounds with intermediate polarity have the highest activity. This could be related to the bioavailability of these compounds to ticks and microorganisms. There was a very large difference in the activity of the n-butanol fraction of leaves and the n-butanol fraction of tubers indicating that different acaricidal compounds may be present in leaves and tubers of $M$. edulis.

It is interesting that there was a very large difference in the activity of $M$. edulis leaves extracted with water and surfactant $(15.3 \%$ mortality) compared to the acetone extract (97\%). This may be related to the difference in using fresh or dried leaves. In the case of the four acetone extracts with the highest activity, there was an excellent correlation between the activities of the watersurfactant and the acetone extracts $\left(R^{2}=0.997\right)$ confirming that the surfactant succeeded in extracting compounds of the same activity.

\section{Conclusions}

Water, as used under laboratory conditions does not extract acaricidal compounds from any of the 13 plant species used by Zimbabwean smallholder farmers to control ticks according to an ethnoveterinary survey. Acetone has been demonstrated by many authors to be an excellent extractant for antimicrobial, antiparasitic and acaricidal compounds. Acetone extracts of the majority of plants used traditionally to control ticks had good to excellent activity against the cattle tick $R$. (B.) decoloratus. Water is, however, practically the only extractant available for most of the smallholder farmers [18]. Several authors have deduced that intermediate polarity compounds are active against many plant and animal pests. Many plants growing in rural areas contain metabolites with useful activities. By adding $1 \%$ of commercial liquid soap, acaricidal compounds were extracted and some of the plant extracts had excellent activity. Adding soap to the water makes it possible for farmers that do not have access to commercial synthetic acaricidal products to exploit the biological activity of pesticidal plants growing in their environment.

\section{Methods \\ Study site}

The in vitro studies were conducted in the Phytomedicine Laboratory, Faculty of Veterinary Science, University of Pretoria in South Africa and at the Central Veterinary Laboratories, Harare, Zimbabwe.

\section{Plant material collection}

The plant species collected were in nature from the places around the communities who reported use of them in Muzarabani, Chiredzi, Sanyati and Matopo districts [9]. In Zimbabwe, no special permission is required for collection of plant materials for local research. However, before the survey and subsequent collection of the plant samples, the traditional leadership of the communities were appraised of the intent of the research and the need for collection of samples for further scientific investigations. The plant parts harvested were based on the information received from the farmers in those areas during the ethnobotanical survey [9]. Samples of the plants were taken to the National Herbarium and Botanic Gardens of Zimbabwe for identification and preparation of herbarium voucher specimens. Mr. Christopher Chapano, the resident botanist, identified the plant species and prepared the voucher specimens (Table 4).

Table 4 Plant species used and voucher specimen details

\begin{tabular}{|c|c|c|c|}
\hline Plant species & Family & $\begin{array}{l}\text { District } \\
\text { collected }\end{array}$ & $\begin{array}{l}\text { Voucher specimen } \\
\text { number }\end{array}$ \\
\hline Albizia amara & Fabaceae & Muzarabani & Nyahangare E38 \\
\hline Aloe excelsa & Aloaceae & Muzarabani & Nyahangare E29 \\
\hline Carissa edulis & Apocynaceae & Sanyati & Nyahangare E39 \\
\hline Cassia abbreviata & Fabaceae & Sanyati & Nyahangare E72 \\
\hline Cissus quadrangularis & Vitaceae & Chiredzi & Nyahangare E6 \\
\hline Croton gratissimus & Euphorbiaceae & Matopo & Nyahangare E48 \\
\hline Kleinia sp. & Asteraceae & Matopo & Nyahangare E50 \\
\hline Maerua edulis & Capparaceae & Chiredzi & Nyahangare E5 \\
\hline Monadenium lurgadae & Euphorbiaceae & Chiredzi & Nyahangare E15 \\
\hline Osyris lanceolata & Santalaceae & Chiredzi & Nyahangare E49 \\
\hline Ricinus communis & Euphorbiaceae & Matopo & Nyahangare E42 \\
\hline Terminalia sericea & Combretaceae & Matopo & Nyahangare E36 \\
\hline Ornithogalum sp. & Liliaceae & Chiredzi & Nyahangare E59 \\
\hline
\end{tabular}




\section{Preparation of plant treatments}

\section{Preparation of crude water extracts of some species}

The plant species selected for water extraction were based on the frequency of use by rural farmers and the absence of well documented investigations on activity. Fresh leaves of Maerua edulis Gilg \& Ben Dewolf., Cassia abbreviata Oliv., Datura stramonium L., Monadenium lugardae N.E.Br., fleshy stems of Cissus quadrangularis L., Aloe excelsa L. Burm.f. and root tubers of Maerua edulis (Table 1) were crushed separately using a pestle and mortar and mixed with distilled water to make $10 \% \mathrm{w} / \mathrm{v}$. A separate set of treatments was prepared where 1\% $v / v$ surfactant (Sunlight liquid soap produced by Unilever Pty Ltd) was added to optimise the extraction and the extract's spreading effects before grinding [22]. This liquid soap is widely available in southern Africa. The active components are: sodium dodecylbenzene sulphonate, sodium laurylethersulphonate, sodium xylene sulphonate, ethanol and cocamidopropyl betaine. The percentage of the compounds is a trade secret. The mixtures were left for $24 \mathrm{~h}$ after which they were filtered with a Whatman No 1 filter paper to remove the plant residues.

\section{Preparation of acetone extracts}

A total of 13 plant species used traditionally with different rating by farmers were used: Monadenium lurgadae N.E. Br., Cassia abbreviate Oliv., Kleinia sp. Mill., Maerua edulis (Gilg. \& Benedict) (leaves and tuber), Cissus quadrangularis L., A. excelsa, Osyris lanceolata Hochst. \& Steud. ex A. DC., Albizia amara (Roxb.) Boivin., Ricinus communis L., Carissa edulis Vahl, Terminalia sericea Burch. ex DC., Croton gratissimus Burch. var. gratissimus, Ornithogalum sp. L. The Kleinia and Ornithogallum plants could not be identified to the species level. This is not too strange in southern Africa containing more than $10 \%$ of the world's species diversity where new species are frequently discovered and the taxonomic treatment of some taxa have not been completed yet. Herbarium voucher specimens are available and the district in which the plant was collected is provided in Table 4 for scientists wanting to repeat the work.

The dried ground plant material $(5 \mathrm{~g})$ was mixed with acetone $(50 \mathrm{~mL})$, shaken vigorously for $20 \mathrm{~min}$, and then centrifuged at $1700 \mathrm{rpm}$ for $10 \mathrm{~min}$. The supernatant was filtered through a Whatman No. 1 filter paper into preweighed glass jars. The extraction procedure was repeated three times for each aliquot of plant material. The solvent was dried under vacuum using a rotary evaporator. After drying, $0.1 \mathrm{~g}$ of the residue was dissolved in $1 \mathrm{~mL}$ of acetone to make a $10 \% \mathrm{w} / \mathrm{v}$ (or $100 \mathrm{mg} / \mathrm{mL}$ ) concentration used in the tick bioassays. Previous studies have shown that acetone alone is not toxic or has very low toxicity to tick larvae and other microorganisms and therefore can be used in bioassays [13, 23, 24].
Preparation of fractions of acetone extracts of Maerua edulis The acetone extracts of the leaves and tuber were dried and dissolved in hexane and put in an ultrasonic water bath for $30 \mathrm{~min}$. The solution was transferred to a separating funnel and an equal volume of water added. The water and the hexane fractions were collected separately and the water fraction returned to the separatory funnel. Chloroform was added and an equal amount of distilled water was added. After separation of the fractions, the chloroform and water were collected separately. The water fraction was returned to the funnel and butanol added. After partitioning, the butanol and water fractions were also collected separately. These processes yielded a series of fractions with different polarities. All the extracts were dried under a stream of cold air at room temperature and the dry extracts stored in a cold room at $4{ }^{\circ} \mathrm{C}$. A day before incubation with the tick larvae, approximately $0.2 \mathrm{~g}$ of the extract was diluted in approximately $20 \mathrm{~mL}$ of double distilled water containing $0.02 \%$ Triton $\mathrm{X}-100$ and $1 \%$ acetone (diluent). The solution was vortexed for up to $10 \mathrm{~min}$ and then put in a sonicator at $37^{\circ} \mathrm{C}$ for $10 \mathrm{~min}$ to dissolve the extract in the diluent [25]. Undissolved or partially dissolved extracts after these procedures were used without further treatment. The concentrations of the plant extracts $(10 \mathrm{mg} / \mathrm{mL})$ were not corrected for incomplete dissolution in the diluent.

\section{Adapted Shaw Larval Immersion Test (SLIT)}

The SLIT method described by Shaw in [25] was used to determine the efficacy of plant extracts against ticks. The method was modified by increasing the larval incubation post treatment to $72 \mathrm{~h}[18]$.

\section{Experimental procedure and data analysis}

The procedure described in [25] was followed using 1621 day old tick larvae in all experiments. Using a soft small paint brush, approximately 200 larvae were placed between two round Whatman No. 1 filter papers (diameter $120 \mathrm{~mm}$ ) to form a larvae sandwich which was placed in a pie plate (diameter $140 \mathrm{~mm}$ ). About $10 \mathrm{~mL}$ of the test solution from the plant extract was poured carefully over the sandwich to expose the larvae to the plant extract for $30 \mathrm{~min}$. After the $30 \mathrm{~min}$, any excess solution was drained off using paper towels and the sandwich transferred to a clean dry filter paper (diameter 250 $\mathrm{mm}$ ). The sandwich was opened and each half placed on the dry filter paper. Approximately 100 larvae were brushed off the filter paper to a clean filter paper envelope which was crimped and closed and finally kept in an incubator set at temperature $26^{\circ} \mathrm{C} \pm 2$ and relative humidity (RH) 70-90\%) [21]. The experiment for each plant extract was duplicated. The $0.1 \%$ acetone diluent and Triatix $^{\ominus}(12.5 \%$ EC amitraz-based compound 
manufactured by Ecomed Manufacturing, Belmont, Zimbabwe for Coopers Zimbabwe Pty Ltd) applied at the prescribed label dilution rate of $0.002 \% \mathrm{v} / \mathrm{v}$, were used as the negative and positive controls, respectively. The number of dead larvae was determined after $72 \mathrm{~h}$. The efficacy of each extract was determined by comparing mortality in the test extracts against the mortality in the negative control from which a corrected mortality (CM) was eventually calculated using Abbott's formula [26]:

$$
C M=\left[i-\frac{c}{100}-c\right] * 100
$$

Where $\mathbf{i}=\%$ mortality in test extract; $\mathbf{c}=\%$ mortality in negative solvent control (Diluent); $\mathbf{C M}=\%$ corrected mortality.

\section{Abbreviations}

CM: Corrected mortality; Ltd.: Limited; Pvty: Private; RH: Relative humidity; SEM: Standard error of the mean; SLIT: Shaw Larval Immersion Test

\section{Acknowledgements}

The National Herbarium and Botanic Gardens of Zimbabwe and in particular Mr. C. Chapano helped with the correct identification of the plant species. The Central Veterinary Laboratory of Zimbabwe provided tick rearing advice, laboratory facilities and expertise.

\section{Authors' contributions}

BMM and JNE conceptualised the study, ETN did the practical work and drafted the initial manuscript, BMM supervised the work in Zimbabwe, LMM assisted with laboratory experiments in South Africa, JNE supervised the work in South Africa and revised the final draft manuscript and submitted it. All authors have read the manuscript and approved its submission.

\section{Authors' information}

The first author is a PhD student and all the other authors are involved with the Universities of Pretoria and Zimbabwe.

\section{Funding}

This work was partly supported by the European Commission's European Development Fund ACP S\&T Programme grant FED/2013/329272 (OPTIONs) and partly by the Technology Innovation Agency in South Africa.

\section{Availability of data and materials}

Data is available from the corresponding author.

\section{Ethics approval and consent to participate}

Because in Zimbabwe no special permission is required for the collection of plant material for local research, no ethical approval was required for this study. All the traditional healers agreed that their information could be used for this study. No licenses were required for this work.

\section{Consent for publication}

Not applicable.

\section{Competing interests}

The authors declare that they have no competing interests.

\section{Author details}

'Department of Animal Science, Faculty of Agriculture, University of Zimbabwe, P O Box MP167, Mt Pleasant, Harare, Zimbabwe. ${ }^{2}$ Phytomedicine Programme, Faculty of Veterinary Science, University of Pretoria, Private Bag X04, Onderstepoort, Pretoria 0110 , South Africa. ${ }^{3}$ Department of Soil Science \& Agricultural Engineering, Faculty of Agriculture, University of Zimbabwe, $P$ O Box MP167, Mt Pleasant, Harare, Zimbabwe.
Received: 21 January 2019 Accepted: 5 September 2019

Published online: 09 November 2019

\section{References}

1. George JE, Pound JM, Davey RB. Chemical control of ticks on cattle and the resistance of these parasites to acaricides. Parasitology. 2004;129(S1):S353-66.

2. Moyo B, Masika PJ. Tick control methods used by resource-limited farmers and the effect of ticks on cattle in rural areas of the Eastern Cape Province, South Africa. Trop Anim Health Prod. 2009:41(4):517-23.

3. Jongejan F, Uilenberg G. The global importance of ticks. Parasitology. 2004; 129(07):S3.

4. Adenubi OT, Fasina FO, McGaw L, Eloff JN, Naidoo V. Plant extracts to control ticks of veterinary and medical importance: A review. S Afr J Bot 2016;105:178-93.

5. Isman MB. Botanical insecticides, deterrents, and repellents in modern agriculture and an increasingly regulated word. Annu Rev Entomol. 2006;51:45-66.

6. Adenubi OT, McGaw LJ, Eloff JN, Naidoo V. In vitro bioassays used in evaluating plant extracts for tick repellent and acaricidal properties: a critical review. Vet Parasitol. 2018;254(March):160-71.

7. Benelli G. Saudi journal of biological sciences managing mosquitoes and ticks in a rapidly changing world - facts and trends. Saudi J Biol Sci. 2019; 26:921-29.

8. Adenubi OT, Ahmed AS, Fasina FO, McGaw LJ, Eloff JN, Naidoo V. Pesticidal plants as a possible alternative to synthetic acaricides in tick control: a systematic review and meta-analysis. Ind Crop Prod. 2018;123(August 2017): 779-806.

9. Nyahangare ET, Mvumi BM, Mutibvu T. Ethnoveterinary plants and practices used for ecto-parasite control in semi-arid smallholder farming areas of Zimbabwe. J Ethnobiol Ethnomed. 2015;11(1):30 Available from: http://www. scopus.com/inward/record.url?eid=2-s2.0-84930666291\&partnerlD=tZOtx3y1.

10. Ndhlovu DN, Masika PJ. Ethno-veterinary control of bovine dermatophilosis and ticks in Zhombe, Njelele and Shamrock resettlement in Zimbabwe. Trop Anim Health Prod. 2012;45(1):525-32.

11. Eloff JN. Which extractant should be used for the screening and isolation of antimicrobial components from plants? J Ethnopharmacol. 1998;60(1):1-8.

12. Kotzé M, Eloff JN, Houghton PJ. Extraction of antibacterial compounds from Combretum microphyllum (Combretaceae). S Afr J Bot. 2002;68(1):62-7 Available from: http://linkinghub.elsevier.com/retrieve/pii/S0254629915304427.

13. Resende JD de SA, Daemon E, Monteiro CM de O, Maturano R, de APMC, Rodrigues AFSF. Toxicity of solvents and surfactants to Amblyomma cajennense (Fabricius, 1787) (Acari: Ixodidae) and Dermacentor nitens (Neumann, 1897) (Acari: Ixodidae) larvae. Exp Parasitol. 2012;131(2):139-42.

14. Eloff JN, Angeh IE, McGaw LJ. Solvent-solvent fractionation can increase the antifungal activity of a Melianthus comosus (Melianthaceae) acetone leaf extract to yield a potentially useful commercial antifungal product. Ind Crop Prod. 2017;110(November):103-12.

15. Nyahangare ET, Mvumi BM, Maramba T. Acute oral mammalian toxicity and effect of solvents on efficacy of Maerua edulis (Gilg. \& Ben.) de wolf against Rhipicephalus (Boophilus) decoloratus Koch, 1844 (Acarina: Ixodidae), tick larvae. Biomed Res Int. 2016:1-8 Available from: https://doi.org/10.1155/ 2016/7078029

16. Nyahangare ET, Mvumi BM, Magona C, Eloff JN. An aqueous extract of Maerua edulis (Gilg \& Ben) DeWolf tuber is as effective as a commercial synthetic acaricide in controlling ticks on cattle in vivo. Ind Crop Prod. 2017; 110(September):88-93.

17. Gonçalves K, Toigo E, Ascoli B, Von Poser G, Ribeiro VLS. Effects of solvents and surfactant agents on the female and larvae of cattle tick Boophilus microplus. Parasitol Res. 2007;100(6):1267-70.

18. Wellington KW, Leboho T, Sakong BM, Adenubi OT, Eloff JN, Fouche G. Further studies on South African plants: Acaricidal activity of organic plant extracts against Rhipicephalus (Boophilus) microplus (Acari: Ixodidae). Vet Parasitol. 2017;234:10-2.

19. Talib WH, Mahasneh AM. Antimicrobial, cytotoxicity and phytochemical screening of Jordanian plants used in traditional medicine. Molecules. 2010; 15(3):1811-24

20. Zorloni A, Penzhorn BL, Eloff JN. Extracts of Calpurnia aurea leaves from southern Ethiopia attract and immobilise or kill ticks. Vet Parasitol. 2010;168: 160-4.

21. Luo X, Pires D, Aínsa JA, Gracia B, Mulhovo S, Duarte A, et al. Antimycobacterial evaluation and preliminary phytochemical investigation 
of selected medicinal plants traditionally used in Mozambique. J

Ethnopharmacol. 2011;137(1):114-20.

22. Amoabeng BW, Gurr GM, Gitau CW, Stevenson PC. Cost: benefit analysis of botanical insecticide use in cabbage: implications for smallholder farmers in developing countries. Crop Prot. 2014;57:71.

23. Nyahangare ET, Mvumi BM, Maramba T. Acute oral mammalian toxicity and effect of solvents on efficacy of Maerua edulis ( Gilg. \& Ben.) De wolf against Rhipicephalus (Boophilus) decoloratus Koch, 1844 (Acarina: Ixodidae), tick larvae. Biomed Res Int. 2016;2016:7078029.

24. Adamu M, Naidoo V, Eloff JN. Efficacy and toxicity of thirteen plant leaf acetone extracts used in ethnoveterinary medicine in South Africa on egg hatching and larval development of Haemonchus contortus. BMC Vet Res. 2013;9(1):38 Available from: http://www.pubmedcentral.nih.gov/ articlerender.fcgi?artid=3599279\&tool=pmcentrez\&rendertype =abstract.

25. Mekonnen S, Bryson NR, Fourie LJ, Peter RJ, Spickett AM, Taylor RJ, et al. Comparison of 3 tests to detect acaricide resistance in Boophilus decoloratus on dairy farms in the Eastern Cape Province, South Africa. J S Afr Vet Assoc. 2003;74(2):41-4.

26. Abbasi AM, Khan SM, Ahmad M, Khan MA, Quave CL, Pieroni A. Botanical ethnoveterinary therapies in three districts of the Lesser Himalayas of Pakistan. J Ethnobiol Ethnomed. 2013;9:84 Available from: http://www pubmedcentral.nih.gov/articlerender.fcgi?artid=3904763\&tool= pmcentrez\&rendertype $=$ abstract.

\section{Publisher's Note}

Springer Nature remains neutral with regard to jurisdictional claims in published maps and institutional affiliations.

Ready to submit your research? Choose BMC and benefit from:

- fast, convenient online submission

- thorough peer review by experienced researchers in your field

- rapid publication on acceptance

- support for research data, including large and complex data types

- gold Open Access which fosters wider collaboration and increased citations

- maximum visibility for your research: over $100 \mathrm{M}$ website views per year

At $\mathrm{BMC}$, research is always in progress.

Learn more biomedcentral.com/submissions 